FABULARIO 


\section{Con un vaso de vodka}

\section{Por Alejandra Ruz ${ }^{1}$}

Kalil me levanta en sus brazos y me da un beso en la boca. Me mira con sus grandes ojos negros y sonríe al sentir mis patas tensas en su cara. Ya en el suelo, en un rincón de la cocina, me sirve leche y galletas (mis favoritas) y acaricia mi cola. Se sienta en la mesa, endulza su café y toma el periódico. Como todas las mañanas, lee sólo los titulares, y luego uno o dos párrafos de las noticias. También lee las columnas de opinión, las de los periodistas que no se cohíben por el momento político o por el salario, porque aquellos que sí lo hacen logran enojarlo, y entonces me pregunta por qué ellos se venden. Yo lo miro, lo escucho, aunque todo eso que dice no tiene para mí ni la más mínima importancia.

Come galletas con su café y se va a vestir. Lo sigo. Deja caer al suelo la bata de algodón azul oscuro y descalza las pantuflas a cuadros que le regaló su mamá. Desnudo, frente al espejo, se rasca la barriga que le ha crecido desde que sale a tomar con Fredy todos los viernes por la noche. “¿Qué más puedo hacer luego de trabajar como un burro toda la semana? Siempre estoy frente al computador, solucionando las estupideces de los demás. Diez años haciendo lo mismo. Ya estoy harto de eso". A Kalil le parece que habla todo el día, pero al levantarse de su pequeño y silencioso cubículo a tomar café en el pasillo, un "Hola" desde su ronca voz le recuerda que ha hablado todo el tiempo consigo mismo. Como ahora.

Espanta sus pensamientos con la mano, sin darse cuenta, y escoge la camisa a cuadros azules y el jean índigo. Tiene siete camisas de cuadros azules y siete jeans índigo. Las demás camisas son diferentes: cuadros amarillos, cuadros verdes, cuadros aguamarina... ¡Qué gusto! Pero no puedes culparlo por eso, su madre se las regala todas, en cada cumpleaños, navidad o San Valentín. Aunque Helena no necesita una fecha especial para regalarle camisas, zapatos o corbatas, y a Kalil ya no le importa si se viste de azul o verde, a cuadros o a rayas.

\footnotetext{
${ }^{1}$ Médica de la Universidad de Cartagena. Especialista en Medicinas Alternativas. Practica el Chi Kun, la caligrafía china y el Teatro Creativo Sanador en la Escuela Neijing. Co-fundadora del Taller Permanente de Escritura Creativa (Cartagena, 2010-). e-mail: aruzrojas@gmail.com
} 
-¡Te pareces tanto a tu papá! Qué haría yo sin ti, mi nene, sobre todo desde que me salió eso en los exámenes -le dice, caminando a su alrededor, pisando corto y rápido con esos gastados zapatos de tacones café, esos zapatos que nunca me ven, esos que tanto detesto. Me alejo sin perder de vista sus pisadas. Ella observa sus brazos, los puños, la caída de la camisa en la espalda. Y entonces le da una palmadita en la nalga.

-¡Mamá! -gruñe él. Pero ella, con su voz chillona, lanza un gritillo de placer.

Kalil no suele usar corbatas ni pantalones de pliegues (por eso siempre se acumulan en el ropero), no obstante, su madre no deja de comprarlos. Ella insiste. Quiere que su hijo, aunque más alto, flaco y desgarbado que su padre (como ella lo menciona), se parezca a él, le devuelva por un momento su voz, su mirada, su sonrisa. Pero Kalil no sonríe. Al menos no a ella. Y habla muy poco. Si yo fuera él, haría lo mismo.

Termina de vestirse y baja al comedor. María ha llegado, le sirve el desayuno, e inclinándose en la mesa, le muestra esos senos que él tanto desea, que él tanto conoce. Lo mira a los ojos, sonriente, pero Kalil sólo mira sus senos, algo que ella también disfruta. María da un salto delante de mí (lo que me hace correr a refugiarme tras las patas de la mesa) y desaparece a la voz de Helena. Kalil mira sus nalgas prominentes, su falda minúscula y sus brillantes piernas morenas. Puedo verlo ahora cada domingo de misa matinal, cuando la toma por sus caderas, la inclina en esa misma mesa, y avanza repetidas veces dentro de su uniforme.

-Nene, no olvides el jugo de tomate y el sándwich. Te lo puse al lado del morral ¡Aún no sé por qué no usas el maletín de cuero que te regalé! Yo sé que es viernes, pero no llegues tarde hoy. Tu tía Gloria viene a cenar -grita Helena desde la cocina, y el taconeo desaparece escaleras arriba, hacia el cuarto principal.

Me gusta husmear lo que hace Helena cuando está sola, así que subo a dar un vistazo. Es el aniversario de la muerte del padre de Kalil, fecha que él no quiere recordar en absoluto. Yo tampoco. La verdad es que no lo conocí. Entonces salto al nochero, detrás de Helena, y la veo desempolvar el álbum de fotos de los días de cacería de Saulo y su hermano Raúl, los dos en los brazos de Helena; las del matrimonio de Saulo y Helena, ella con unos kilitos de más. Veo también los recortes de las noticias del accidente de cacería, la muerte de Saulo y la desaparición de Raúl. 
-No debí decírselo, no debí decírselo -repite Helena, sentada en su cama frente a los recuerdos, llorando en silencio. Siempre me recuerda a esas mujeres que María ve llorar en la televisión. “Qué miras?”, me dice. "¡Largo de aquí!". Vuelvo rápidamente al pasillo y sigo a Kalil, que ya en su cuarto busca el reloj en el cajón del nochero y observa de nuevo las cápsulas azul con blanco. Le han dicho que si las combina con vodka no hay marcha atrás. Decide dejarlas en casa, por ahora. Cierra el cajón y carga su morral, olvidando intencionalmente la bolsa de papel con el jugo de tomate y el sándwich. Baja las escaleras, mientras yo camino hacia mi sofá junto a la ventana, lentito. No hay prisa. Ya sé que desde aquí puedo verlo llegar al jardín, encender su auto, mirar atrás y despedirse de mí, justo antes de alejarse hacia el trabajo. Ya está. Ahora, a dormir.

Oigo voces alteradas en la cocina. Es muy temprano para despertar de mi siesta ¿Por qué tanto alboroto? Medio dormido, empujo mi espalda en una curva hacia arriba. Estiro luego mis patas hacia adelante, para recobrar mi fuerza. La tarde es calurosa y la luz del sol ha atravesado la ventana, cayendo sobre mí. Salto del sofá y siento dolor en una de mis patas traseras: los cubitos de atún en las noches no me hacen tanto bien iQué importa, son deliciosos! Bajo las escaleras con dificultad y avanzo hacia la rendija de la puerta de la cocina, observando los zapatos de tacón café y los tenis blancos de María.

-¿Por qué insistes en contradecirme? Te he dicho que al nene no le gustan los fríjoles con carne ¡Estás provocándome un colapso!

A Kalil sí le gustan los fríjoles con carne. Le gusta particularmente el sabor de la carne de María. Y Helena lo sabe. Por eso María se irá hoy de la casa. Al igual que Tania, Lola y Teresa, se irá por un plato mal lavado, una palabra de más, o si no descubre y devuelve el anillo que Helena ha plantado en su bolsillo. Helena empuja la puerta de la cocina tan rápido, que casi no logro escapar.

- ¡Qué cosa con este animal! -me dice- ¡Siempre en el medio!... Y ya deja de mirarme así, ni que leyeras los pensamientos.

María, al verme agazapado en un rincón, acaricia mi cabeza y me acerca un plato de jugosas y crujientes galletitas de carne. La extrañaré: sólo yo la echaré de menos. Regreso al sofá a lamer mi pelo y reanudar mi siesta.

Kalil regresa a las seis de la tarde y yo lo espero en la ventana. "Rrrguauauao", le digo. Se sienta en la cama y deja en la alfombra 
las croquetas de atún. Acaricia, con su pie ya descalzo, mi espalda. Acostado de lado en el suelo, me apoyo con las cuatro patas en el nochero y cierro los ojos. Él lleva su pie hasta mi vientre y lo pellizca, lo que me hace abrir los ojos y sacudir la cola con fuerza de un lado a otro. "No me gusta, Kalil, no insistas". Él continúa, por lo que muerdo su pie, tomándolo entre mis garras. "Te lo advertí". Escapa rápido, riéndose: sabía de mis intenciones. Vuelve a mi espalda, dando esos pasitos con los dedos que me hacen agarrarme del nochero y cerrar los ojos, otra vez. Uhmm, eso sí me gusta...

-Nene, baja ya. ¡Tu tía está aquí!... Si supieras lo de María... Esa atrevida resultó amiga de lo ajeno.

Kalil saca de su morral una botella de licor blanco y abre el nochero, contando en su mano una a una las cápsulas azul con blanco. Rozo su brazo, después de saltar a la cama. "Arrguauauao", le digo de nuevo. No me escucha. Observa su mano y se sirve despacio, escuchando el sonido del líquido que llena el vaso, una, dos veces. Se acuesta en la cama con la vista al techo. Sobre su barriga muevo mis cuatro patas, insinuando mis garras al soltar su camisa. Pero Kalil sólo mira fijo al techo, sólo al techo. Helena lo llama de nuevo. Él no la escucha. Toma el vaso y se sirve de nuevo, pensando cada sorbo. Cierra el nochero, con las cápsulas que trajo desde hace tres semanas y que cuenta en su mano todos los viernes, con cada vaso de vodka. 